\section{Frank K. Gibson}

Frank K. Gibson, 64, died on November 28,1988 , while playing tennis with his wife Rose near their retirement home in Titusville, Florida. Frank was born in Morgantown, West Virginia. Following serv$\mathrm{j}_{\mathrm{e}} \mathrm{e}$ in World War II, where he was a tiecorated pilot, he completed his undergraduate and master's degree work at West Virginia University, and also served as an instructor. He completed his doctorate at the University of North Carolina in Chapel Hill in 1953 and joined the faculty at the University of Virginia. He came to the University of Georgia first in 1956 and served two years as Director of the Bureau of Public Administration before returning to the University of Virginia. He re-joined the University of Georgia faculty in 1959 until ill health forced his retirement in 1980. After retirement, Frank worked on a part-time basis at the University of Georgia Institute of Government and later at the University of West Florida and the University of Central Florida. He retired from the latter position in 1987.

Frank's contributions were immense. He was an active scholar, from his first publication of a monograph at the Bureau of Public Administration at West Virginia University in 1949 until his last publication in the Public Administration Review in 1986. His scholarly interest ranged widely and included criminal justice, local government, public management, and policy analysis. His contribution to developing the graduate program in the department of political science at the University of Georgia was critical. He served as director of graduate studies from 1967 until 1970, and as director of the graduate program in public administration from 1971 until 1975. He directed dissertations for more than 36 students and served on more than 100 doctoral dissertation reading committees in a variety of disciplines. Frank felt great concern for students and took great care in exercising his instructional responsibilities. This facet of his contribution was recognized in 1978 when he received the highest teaching award given in the University of Georgia College of Arts and Sciences. Frank also had a special gift of relating to practitioners. In all of his academic positions he sought out practitioners and participated in continuing education activities with them. Groups he worked with included numerous federal government agencies, state agencies in South Carolina, Georgia, Alabama, and Florida, and city manager associations in Georgia, South Carolina, and Florida.

Frank was the kind of colleague who makes the profession of political science rewarding. He was a warm and generous person who readily dispensed advice when asked and whose incisive views on passing events sprang from a high quality education and as good an integration of lessons from the field of practice and from theory as I have observed. Frank also had a quick wit but was not hesitant about making the needed observation to prick the bubble of a fatuous comment or superficial observation. His life exalted scholarship and infected his colleagues, students, and practitioners with the desire to search for the truth more diligently.

Delmer D. Dunn

University of Georgia

\section{Alpheus Thomas Mason}

Editor's Note: Alpheus Mason, McCormick Professor of Jurisprudence, Emeritus at Princeton University, and former vice president of the American Political Science Association, died October 31, 1989 at his home in Princeton after a long illness. He was 90 years old. Mason was a graduate of Dickinson College and received his doctorate from Princeton in 1923. He joined the Princeton faculty in 1925. The following eulogy was delivered at his memorial service by his colleague, Walter F. Murphy.

"Tell me what I ought to know." That was Alph's typical greeting, one he borrowed from Brandeis. He would say it in a jocular tone, but he meant it seriously. He was always eager to learn and eager to pass on to others what he had learned. The corpus of his writing is huge-more than a hundred articles and 22 books, ranging from slim scholarly monographs to hefty judicial biographies to texts and readers. One of his texts is now in its ninth edition, another its fourth; one of his scholarly books sold so well that it went through three editions; and his monumental biography of Brandeis was a Book-of-the-Month Club Selection and stayed on the bestseller list for five months.

But the quantity and popularity of his work were distant seconds to its quality. If Alpheus Mason did not invent the field of judicial biography, he perfected it. The prizes he wonthe American Library Association and the Francis Parkman prizes among others-so testify. The Pulitzer Committee voted his Harlan Fiske Stone the award for biography for 1956, but Joseph Kennedy intervened and used his influence to have the decision reversed and the award assigned to the book published under his son's name, Profiles in Courage.

Alph once remarked that everything any of us wrote was in some sense autobiographical. Almost a decade ago I heard him read a memorial to his dear friend and former student, Julian Boyd:

\footnotetext{
He pioneered in a vast, unexplored field, setting standards of meticulous research, painstaking accuracy, and informed judgment which will shine as a beacon in the years ahead. Originality . . . and craftsmanship mark his legacy. . . . His very presence, speech, and literary style, even the timbre and cadence of his voice, spelled elegance. Some are dazzled by his English prose, not realizing that he was its master not its slave. Happiness was special, too. He enjoyed in the ancient Greek sense: "the exercise of vital powers along lines of excellence in a life affording them scope."
}

All of us who knew Julian Boyd recognized that Alph had captured the essence of the man; all of us who knew Alph recognized that he had also captured his own essence, including the happiness he found in 55 years of marriage with Christine. I used to tease him that she was really the author of many of his books. In all seriousness, he would say she was his constant co-author. No one person, he argued, is good enough to 
write a book alone. Her literary skills augmented his own. Even more important, her dedication to him-and his to her-made his life full and fully human. "Marrying her was the best decision I ever made," he would say. No one ever doubted it.

Coming to Princeton to be the colleague of one of the premier constitutional scholars of the age was daunting. But I took comfort in the sure thought that anyone who wrote so well and so prolifically would not have time to be a good teacher. I could not have been more wrong about his history, his temperament, and even his genes. Let me read a few paragraphs from his unfinished autobiography; they make the point and will also remind us of his style:

It would be extreme to say that my origins are 18th century. My birth in 1899 on Maryland's Eastern Shore, in a rural community 23 miles from the Atlantic, at least a generation behind the rest of the country in technological progress, makes this statement less extreme than it would seem at first thought. Dubbed the "Eastern Sho'," the DelMarVa Peninsula is flat country, suited for truck farming and fishing, especially crabs and oysters. It was then a land of broad vistas, open fields, and isolated white clapboard farmhouses, occasionally broken by patches of woodland where small boys could roam about, freely trapping rabbits and collecting pigeons. Overhead, turkey buzzards circled in graceful spirals, ever in search of prey. People travelled by horse and buggy over dirt roads full of jagged holes and deep ruts. Water was drawn by pumps from wells. Nonexistent modern plumbing necessitated the use of privies. . . . Cooking was done on wood burning stoves or "ranges." . . . Houses were lighted by candles or kerosene lamps, requiring weekly cleaning and trimming of the wicks.

My birthplace was a handsome brick farmhouse ... . two miles south of Snow Hill. Congressman George W. Covington owned it. My father tilled the land and shared the crops.

Pop's formal education ended in third grade, but his self-education in religion and politics continued throughout life. He was an avid reader of the Bible, which inspired him to name me Alpheus. ... . The Bible served as a source book for ideas and lively discussion with men whose formal education greatly exceeded his. A Sunday school teacher, he carried on animated conversations with the local Baptist preacher. Transcending theological issues, they got down to fundamentals. Though largely illiterate, Pop had remarkable ability to articulate ideas ... invariably spiked with wit. I have never met his equal as a mimic and story teller. From age ten to sixteen he was my teacher and ghost writer.

Interest in oratory and public debate moved Pop to collect speeches of outstanding contemporary orators, including William Jennings Bryan, Teddy Roosevelt, and Woodrow Wilson. At a time when money was scarce and technical equipment hard to come by, he bought a gramophone and acquired records so that I might profit by hearing speeches at their best. On at least two occasions my public speaking teacher and mentor was put to a test. Congressman Covington, ardent prohibitionist, offered a prize for students in the 4-room Girdletree School on the topic, "The Best Way to Get Rid of the Liquor Traffic." . . . My (really Pop's) speech won the prize. [Later] at a school program I memorized and delivered a highly dramatic speech from our anthology of literature, entitled "The Death Bed Scene of Benedict Arnold." I can still see my father's proud expression . . . as I received a gold medal, dated 1915 .

Although Alph's graduate students fondly dubbed him "the fastest pen in the east," teaching, as one would expect from this background, came first in his professional life. Indeed, he would subtitle his autobiography "A Teacher's Story." He had only disdain for scholars, even great scholars, who did not love teaching. "He's nothing but an ornament," he said contemptuously about a noted political scientist whom the department was considering. "An ornament. He doesn't care about students."

To watch him lead a graduate seminar was to watch Toscanini conduct a symphony orchestra. Each week each student had to write a paper on one of the "queries" Alph had chosen. But the students could never read their papers in the seminar. Alph would do that before the meeting, remember what each had written, and begin by asking a leading question to one of the participants. He'd listen to the response for a few minutes, then turn to another student and say, "He's claiming your paper is all wrong. Are you going to let him get away with that?" Battle would be joined; from time to time Alph would shift the topic and engage fresh antagonists, but for three hours the argument would never once let up.

It was a trait he never lost. Just before his long illness I took him and two of my preceptors to lunch at the faculty club. As we put the trays down, I heard him say to one: "What do you think about. ..." I missed the next part of the sentence because I had to go back through the line for tea. A few minutes later, I returned to the sound of loud voices; my two preceptors were shouting at each other, one wildly punctuating the air with waving hands. All I said was "Alphhhh." He grinned impishly and shrugged his shoulders as if to reply: "Just wanted to make sure I still have the touch." He did.

His undergraduate lectures-written out in long hand-were always polished and sparkling-evidence of his talent and practice, his father's training, and Christine's literary flair. "I've never given a lecture I didn't later publish," Alph once said. How could it have been otherwise?

Alph was a carrier of ideas, and no vaccine could immunize against his virus. No one who heard him or argued with him could escape deeply caring about how to solve intellectual problems. Nor could one escape the contagion of his enthusiasm for ideas and for clear thinking about ideas. We were all infected. Thank God.

He was not without a few tricks. He knew how to measure an audience and how to count a house. One day when the two of us were walking across the campus, with Alph attacking Felix Frankfurter's jurisprudence with the sort of zeal academics now reserve for Ronald Reagan, he suddenly interrupted himself to speak to an undergraduate: "Mr. Henry, I'm so glad you're better." "Better?" the puzzled young man replied. "Better?" I haven't been sick." "Oh," Alph said in a tone both puzzled and hurt, "you weren't at lecture this morning; I thought you must be ill." I needn't add that the young man never missed another lecture.

Alph could also be maddening. Whenever we disagreed on personnel matters, I, being young and foolish, would always try to convince him. 
He'd listen politely but seldom change his mind. "In my judgment," he'd begin. "But," I would regularly interrupt, "good judgment has to be based on evidence." Just as regularly he would spring the trap: "But $I$ must have good judgment. Didn't I pick you to come here?"' There was no answer, at least none that would strengthen my case.

In his Sonnet \#12 Shakespeare wrote that " 'gainst Time's scythe" no man can make defense except in his offspring. Here Alph blunted Time's blade. His daughter, son-inlaw, three granddaughters, and two great grandchildren live on with Christine. But so do generations of Princeton undergraduates and graduate students, as do students from the fifteen universities at which he taught after his so-called retirement. Many of these people are now journalists, judges, lawyers, and professors. They are fulfilling Alph's usual parting command: "Carry on." If they are not doing so in the Brandeis way, certainly they are in the Mason way. And the world is much the better for it.

Unlike Thomas Wolfe, we shall not have to spend time "remembering speechlessly" or seeking that "lost, and by the wind grieved, ghost"; we need not cry out "come back again." For whenever constitutional scholarship is done, Alph's ghost-Alph's spirit-will be with us, rustling judicial papers, recalling the framers' wisdom, tweaking Felix Frankfurter, and reminding us of the responsibilities and the joys of "free government" and free men's-and free women's-lives.

Walter F. Murphy

Princeton University

\section{Llewellyn E. Pfankuchen}

A devoted and learned member of our profession over many years, Professor Emeritus Llewellyn E. Pfankuchen died in his sleep on August 15,1989 , at age 85 . He had been continuously a member of the American Political Science Association since 1927, and thus, at the time of his death, for a longer period than all but five living members. For forty of those years (1932-72) Llewellyn was a respected member of the fac- ulty at the University of WisconsinMadison.

Llewellyn was born in Oshkosh, Wis., on May 7, 1904, grew up in Minneapolis and graduated magna cum laude from the University of Minnesota (1924). After a stint of public school teaching in Highmore, S.D., he began his graduate education at the University of Illinois, attaining an M.A. in 1926, and completed it at Harvard University with a Ph.D. in 1931. He gained additional teaching experience at the New Jersey Law School, interrupting his graduate work to do so. After completing his doctorate he began his professional career at Duke University but after only one year joined the faculty at Madison (1932). Here he rose from the rank of instructor to that of full professor and was designated chairman of the department in 1944, serving until 1948. He served in 1948 as President of The Midwest Conference of Political Scientists (now the Midwest Political Science Association).

During his long tenure at Wisconsin, Llewellyn taught, at one time or another, nearly every course in the curriculum but the center of his scholarly interest was international law. With a few interruptions he taught the courses in this subject offered by the department throughout his years of service. His Documentary Textbook in International Law (1940) was for years one of the standard works in this field. After World War II, he became deeply interested in the political aspects of international relations and together with a distinguished professor of geography (Richard Hartshorne) completely reorganized the basic courses in this field offered by the department. The new approach focused on the nation-state as a going concern, the relations between the internal and external politics of nations, and the development of institutions for mediating interstate conflicts, combining in each phase the unique insights of geography and political science.

During the New Deal era, Llewellyn served in one of the main sources of national agricultural policy, the Bureau of Agricultural Economics of the U.S. Department of Agriculture, and brought back to the campus his enthusiasm for rural America and its local governmental institutions. His most important public servic was his work during and after World War II in the State Department helping to prepare the groundwork for a new international institution and at the conference in San Francisco (1945) at which the Charter for the United Nations was prepared. His strong support for the U.N. continued throughout his active life. He served on annual state and local commissions providing grassroots support for and understanding of the U.N. and was director for several summers of a seminar in New York City for university students on the U.N. and its operations. The students who were privileged to participate regarded the U.N. experience as one of the high points of their education.

The three of us whose signatures appear below were not only longtime departmental colleagues of Llewellyn's but also, earlier, among his many students-one of us as a graduate student and the other two as undergraduates. Like most of his other students, including several who achieved distinguished careers at other universities or in public service, we admired Llewellyn's teaching and were encouraged by it to continue our study of political science. Then, when fortunate enough to be Llewellyn's colleagues, we came to appreciate his fairness, discriminating judgment, and agreeable disposition. Llewellyn's judiciousness was a model of professional behavior, and his warm friendship was cherished by all of us.

Besides his considerable involvement in University affairs, Llewellyn participated in various civic and community organizations. He loved choral singing and was an early and active member of the Philharmonic Chorus of Madison. He is survived by his wife, Gretchen, and two children, David and Heidi.

William H. Young

Leon D. Epstein

Clara Penniman

University of Wisconsin-Madison

\section{John Adams Wettergreen}

John Adams Wettergreen, 45, died suddenly of a heart attack after a 